\title{
Depicting the Contrast between America and Europe through Symbolic Characters in The Portrait of a Lady
}

\author{
Davood Mohammadi Moghadam ${ }^{a}$, Wan Roselezam Wan Yahya ${ }^{b}$ \\ Faculty of Modern Languages and Communication, University Putra Malaysia, \\ Kuala Lumpur, Malaysia \\ a,bE-mail address: ecodavood_nature@yahoo.com, roselezam@gmail.com
}

\begin{abstract}
Henry James is one of the most prominent American novelists. In spite of a great novelist, he was also one of the important theorists of the novel whose theories were effective in the field of novel. He is mostly famous for his international novels through which he practiced the international theme of 'America versus Europe'. Through this international theme, James depicts the contrast between America and Europe in his works, while it was defined as the duty of American writers of his days to write about this contrast to show America as separated and distinguished from Europe. The Portrait of a Lady is generally accepted to be James' masterpiece. In this novel James practices his international them professionally through his common basic pattern of bringing an American young lady into a European society to show the contrast between America and Europe. This American lady in this novel is the heroine, Isabel Archer, who comes to Europe in the search of a better life and a high culture, but finally is deceived by sophisticated Europeans as the result of her innocence. Actually one of the main contrasts shown in this novel is the conflict between American innocence and European sophistication or high culture. This study is going to discuss that one part of this conflict is represented by James through some symbolic characters in this novel. The study is going to focus on Madam Merle and Ralph, and aims to discuss that it is through Isabel's interaction with these symbolic characters that one part of the contrast between America and Europe is depicted.
\end{abstract}

Keywords: Henry James; International Theme; America versus Europe; Symbolic Characters

\section{INTRODUCTION}

The Portrait of a Lady generally is accepted to be Henry James' great masterpieces, as Clarke confirms in his book, "The Portrait of a Lady (1881) is the first of the list of 'great' novels produced by Henry James" (191). Through this novel, James professionally practiced his famous international theme of 'America versus Europe'. This international theme, which in the other words can be defined as the contrast of America and Europe, is again practiced in this novel through James's common basic pattern which Mohammadi Moghadam believes to be "deceived American lady in Europe" (8886). This deceived American young lady in The Portrait of a Lady is the heroine of the novel, Isabel Archer. It is through her journey from America to Europe that the story is developed. And the characters with whom Isabel interacts through novel are, in some cases, the symbols of America and Europe. One of the ways that 
the international theme is represented in this novel is through these characters especially Madam Merle, and Ralph.

\section{DISCUSSION}

Isabel Archer in this novel is another example of James's common American young and innocent lady, she makes big mistakes because of her innocence. Maybe her first mistake was traveling to Europe with the hope of culture without any knowledge about the reality of it. Her other mistake was to refuse the proposals of nice men as Mr. Goodwood and Lord Warburton, and to marry with a monster who was Osmond, because she misjudges the real personality of Osmond and Madame Merle. But Isabel like a tragic heroine was learnt at her downfall, and as Lee $\mathrm{Yu}$-ch'eng mentioned at the end of the novel Isabel gained knowledge about the reality:

The action of the novel concerns mainly the pilgrimage of Isabel Archer which leads her from ignorance and innocence to knowledge and maturity.....The lessons of the world will put an end to her cloistered innocence, mark her, mature her, and finally form her, so that at the close of the novel, her vision will be drastically different from her previous conception. (89-91)

One of Isabel's biggest mistakes may be her excess confidence and reliance to Madame Merel whom she had not known completely. There is a close similarity between Isabel's attitude towards Madame Merle and Europe, in other words one can declare that Madame Merle was as a symbol of Europe and James used this character to show the mistake or fault of Isabel about Europe. Isabel had not enough and correct knowledge about Europe but blindly had the desire for its high culture, she thought that through Europe she could reach to a better life and could reach to a high culture. In the case of Madame Merle Isabel again had not enough knowledge about her real character but, like her attitude to Europe, she was so impressed by Madame Merle that she thought that Madame Merle could help her to reach to her dream and to a better life, completely like her attitude toward Europe, she mistakenly thought of Madame Merle to possess a high culture.

It was Isabel's aunt Mrs. Touchett who brought Isabel to Europe and similarly, it was Mrs. Touchett who introduces Isabel to Madame Merle. And it was in Europe where Isabel was trapped and deceived by Osmond and again similarly it was Madame Merle who helped Osmond to trick and deceive Isabel. Closely similar in both case of Madame Merle and Europe when Isabel found out the reality about them, she understood that her judgment about them was a big mistake but in both case it was too late. So according to the explanations, one can declare that, James portrayed the image of Europe in the character of Madame Merle.

James believed that although Europe has a high culture, this culture is distorted and corrupted. James shows this quality of Europe in the image of Madame Merle and Osmond. They actually had no high culture but they simulate that they are nourished by high culture of Europe, and with this simulation they wanted only to deceive people and took benefits. It was through displaying of high culture that Osmond was able to deceive Isabel. It was the culture of Europe that attracted Isabel, and similarly it was the pretended culture of Osmond and Madame Merle that attracted Isabel toward them while she was not aware about their real character. As Wegelin mentioned in his book: "Everything in Osmond is a pose; 'his culture, his cleverness, his amenity' all hide an appalling egotism.”(72)

The only person who at first had correctly find out the real personality of Madame Merle, was Ralph, he was the only person who at the beginning of Isabel's acquaintance with Madame 
Merle warned her about Merle's real personality. He thinks that Madame Merle was "too kind" and too perfect to be true, in his description about Madame Merle he believes:

\begin{abstract}
'Her merits are immense' said Ralph. 'She's indescribably blameless; a pathless desert of virtue; the only woman I know who never gives one a chance ... She pushes the search for perfection too far ... her merits are in themselves overstrained. She's too good, too kind, too clever, too learned, too accomplished, too everything. She's too complete, in a word. I confess to you that she acts on my nerves. (James 173-174)
\end{abstract}

So he believes that such a person as Madame Merle could easily deceive an innocent person as Isabel. In the case of Ralph some critics believe that he is James himself, in the novel we see that Ralph is the only person who knows correctly the real character of Madame Merle and Osmond and warned Isabel a lot about them and about her behaviors. He is the only one who has sympathy towards Isabel and "like to put a little wind in her sails."(James 129), and wants to help her to reach to her dreams and ambitions. Similarly James himself concerns a lot about the success of young Americans in Europe, as Ralph had true knowledge about Madame Merle, James had a true knowledge about Europe, as Ralph warned Isabel about the reality of Madame Merle and Osmond, James again warned young Americans about the reality of Europe and as Ralph wanted to help Isabel to reach to her ambitions in Europe and not be deceived, James wished and wanted to help the young Americans to be successful and not be deceived in Europe so he wrote such novels as The Portrait of a Lady.

Other criteria which critics believe that based on it Ralph could be equal to James himself is James's own cousin Minny Temple, who had died very young and James was in love with. In this novel James portrayed his cousin in the image of Isabel, James was in love with her young cousin Minny and too Ralph was in love with her young cousin Isabel, but because of his Physical illness, Ralph did not dare to propose to Isabel. James also had a physical injury in his youth so like Ralph he was not able to enjoy from a proposal to his cousin.

Because of his physical situation, Ralph was an observer in this novel to see and think about the characters and events, as James took the position of an observer in watching and reporting the situation of Americans in Europe. Christof Wegelin about Ralph believed that: "He dramatizes merely James's expectant sympathy with the American quality which Isabel represents the imagination he keeps calling it which is spiritual energy." (67)

Ralph was the actual character who had a high culture, he had a true knowledge about the people around him, he like Henrietta gain advantage from positive side of European culture and was highly civilized and cultured so he was able to judge the characters based on their inner and real personality. As a highly cultured man, he was the only person who was concern about Isabel's fate and ambitions, he was the only partner who could make the expected life which Isabel had the dream of it, but because of his illness he could not be in the list of Isabel's suitors although he had a strong love toward her. Ralph was the only partner whom Isabel was looking for; he had all the qualities which Isabel expected from her desired husband, but because of her innocence and lack of knowledge, Isabel mistakenly saw those qualities in Osmond and chose him, about Ralph and Osmond she believed:

Ralph had something of this same quality, this appearance of thinking that life is a matter of connoisseurship, but in Ralph it was an anomaly, a kind of humorous excrescence, whereas in Mr. Osmond it was the keynote, and everything was in harmony with it. (James 180) 
So Isabel ignored Ralph and married with Osmond, because as a result of her innocence "Isabel was certainly far from understanding him completely" (James 180) and it was after her marriage that she discovered the real character of Osmond. She understood that Osmond was a monster who pretended to be cultured and who pretended to love her because he wanted to deceive her for the interest of her wealth, so Osmond made a terrible and disastrous life for Isabel.

With this contrast between the characters of Ralph who had a real culture and Osmond who only simulate culture, and showing Isabel's fault towards them and her wrong choose, one can say that James is trying to criticize the decision of those young Americans who are going to ignore America and choose Europe to reach to a better life. Maybe James is going to show to young Americans that in contrast of their thought and decision, it is their own country, not Europe, which can provide a better life for them. So as Ralph warned Isabel from Osmond, James wanted young Americans not to trust completely to Europe as Isabel did and saw its miserable result.

Isabel just at the end of the novel understood that the only person who wanted to help her to attain her desires in life was Ralph. At the end when she earned the knowledge in life, she reached to a true understanding about Ralph and Osmond, and about America and Europe. It was at this moment that she discovered that her expectation about Europe's high culture was not correct, and found out that her decision about leaving America and coming to Europe for a better life was a big mistake as her decision about marriage with Osmond. Even in visiting Henrietta, Isabel confessed her mistake in marriage with Osmond. Lee Yu-ch'eng discussed Isabel's awareness about Ralph at the end of novel and its effect on her vision about the reality, more clear:

When Isabel Archer, the heroine of the novel, is leaving Rome for England to see her dying cousin Ralph Touchett.....she learns from Madame Merle that it had been Ralph's idea that she be made a rich woman by her uncle. The revelation of Ralph's arrangement shocks Isabel Immensely....The metaphor James employs here...not only reflects Isabel's sudden realization of her present situation, but also indicates her awareness of the fact that she has long been living in a world of phantasmagoria, "illumined by lurid flashes" which prevent her from perceiving and facing the genuine reality of life. (89)

\section{CONCLUSIONS}

James himself has the experience of being an American who travelled to Europe when he was young, so he had enough experience to make aware the young Americans about the truth of Europe and its society, culture and characters. Through Isabel's journey from America to Europe, James depicts the contrasts between America and Europe, and through her interaction with other characters it is depicted that how America is the place of morality and innocence while Europe is the place of high culture and sophistication. James practice the contrast between America and Europe through most of his works, while writing about this international theme was defined as a duty of American writers oh those days. Actually "the duty that was defined for the American writers of $19^{\text {th }}$ century [...] was to fight against the superiority of Europe over their country in those days" (Mohammadi Moghadam 91).

Isabel had lived in America, where James believed is more concern about morality, so when she confronts a European society and its high culture, she was not aware that this high culture is out of morality. So she trusted everyone there and because of her innocence and lack 
of knowledge she was easily deceived. Although Ralph, as a wise American, warned her al lot, she blindly trusted Osmond and Madame Merle who were Europeanized American so the European society had taken their innocence and had given them enough knowledge to deceitfully simulate a culture and deceive the innocent Isabel.

\section{References}

[1] Clarke Graham. Henry James: Critical Assessments. Vol. 2. Mountfield near Robertsbridge: Helm Information, 1991. Print.

[2] James Henry. The Portrait of a Lady. Vol. XI. Harvard Classics Shelf of Fiction. New York: P.F. Collier \& Son, 1917; Bartleby.com, 2001. <www.bartleby.com/311/.>

[3] Davood Mohammadi Moghadam, Wan Roselezam Wan Yahya. A Study on the International Theme, as a Prominent Subject in the Works of Henry James. International Letters of Social and Humanistic Sciences 17(2) (2014) 85-94.

[4] Mohammadi Moghadam, Davood. Deceived American Young Ladies in Europe, a Basic Pattern of Henry James's International Theme. Journal of Basic and Applied Scientific Research 2.9 (2012) 8886-893.

[5] Wegelin Christof. The Image of Europe in Henry James. Dallas: Southern Methodist University Press, 1958.

[6] Yu-ch'eng Lee. The Portrait of a Lady as a Bildungsroman. American Studies, XII(3) (1982) 89-99. 